\title{
Glue pulmonary embolism and pulmonary oedema as a rare complication after endovascular embolisation of oesophageal varices
}

\author{
Vasileios Rafailidis, Hasti Robbie, Sa Tran, Konstantinos Stefanidis
}

Department of Radiology, King's College Hospital NHS Foundation Trust, London, UK

\section{Correspondence to Dr Vasileios Rafailidis; billraf@hotmail.com}

Accepted 15 December 2019

\section{DESCRIPTION}

A 51-year-old woman presented with dyspnoea of acute onset. The patient had a history of decompensated alcoholic chronic liver disease with portal hypertension and bleeding oesophageal varices treated with transjugular intrahepatic portosystemic shunt and endoscopic glue embolisation, respectively. CT pulmonary angiogram (CTPA) revealed multiple bilateral high-density emboli within lobar, segmental and subsegmental pulmonary arteries (figure 1) with associated radiographic features suggestive of pulmonary oedema (figure 2).

Non-thrombotic pulmonary embolism is defined as the embolisation of pulmonary circulation by any material other than thrombus including different cellular types (adipose, amniotic, neoplastic), micro-organisms, gas and foreign body. ${ }^{1}$ Cyanoacrylates (glue) are frequently used for treatment of variceal bleeding. The liquid monomer polymerises and becomes solid when exposed to blood. Glue embolism has a reported incidence of $0.5 \%-4.3 \%$, with its risk depending on glue volume, injection rate and variceal diameter. ${ }^{2}$ Pathophysiologically, the embolism occurs due to patent portosystemic vascular shunts, present in portal hypertension.

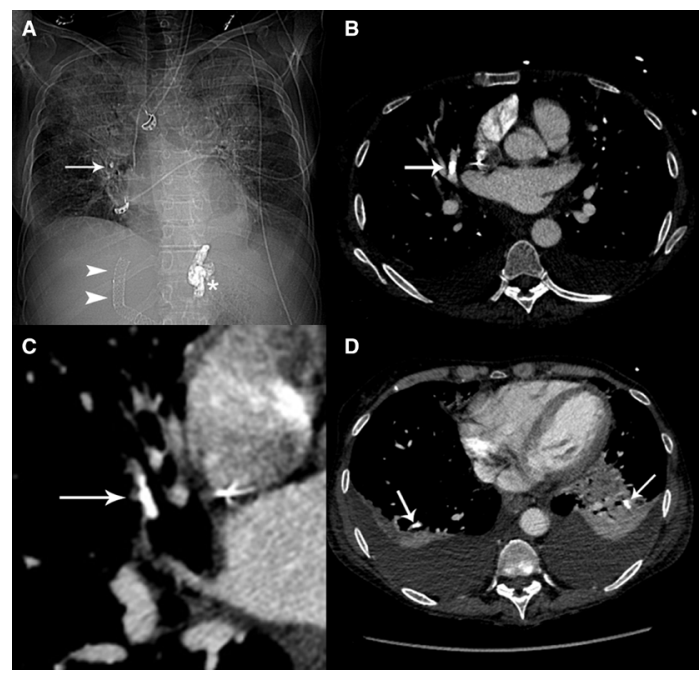

Figure 1 CTPA. review of the scanogram (A) showing radio-opaque material in the right hilum (arrow), bilateral airspace opacification, TIPS (arrowheads) and the glued varices (asterisk). Axial CT images (B-D) showing hyperdense material inside branches of the pulmonary arteries and bilateral pleural effusions with associated passive atelectasis. CTPA, CT pulmonary angiogram; TIPS, transjugular intrahepatic portosystemic shunt.
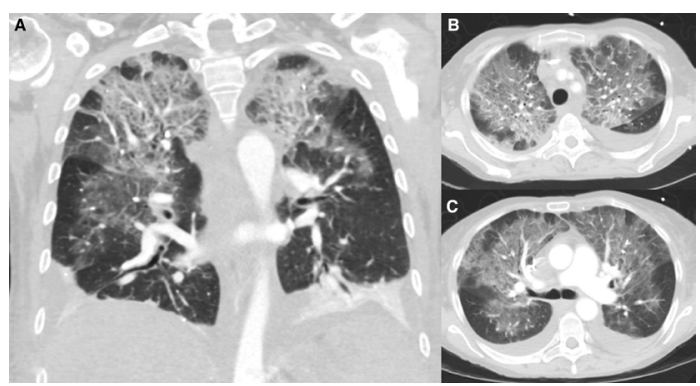

Figure 2 CT coronal (A) and axial images ( $B, C)$ showing bilateral ground-glass opacification and interlobar septal thickening (crazy paving pattern) with bilateral symmetrical pleural effusions, in keeping with pulmonary oedema.

Learning points

- Pulmonary embolism caused by glue used to treat variceal bleeding is a rare entity. Transjugular intrahepatic portosystemic shunt may act as a portosystemic vascular shunt, allowing for the circulation of glue from oesophageal varices to the inferior vena cava and pulmonary circulation.

- CT pulmonary angiogram is the imaging modality of choice for this diagnosis, visualising the foreign material lying within the branches of the pulmonary artery. Pulmonary oedema can be an additional manifestation of this entity.

- It is essential to carefully adjust window settings so that intravenous contrast material does not obscure the embolised material.

CTPA represents the primary imaging modality for detection of embolic material within the pulmonary arteries and evaluation of parenchymal changes. Window setting should be carefully adjusted so that contrast enhancement does not obscure the embolic material. Parenchymal findings include pulmonary oedema, although glue plugs can be colonised by bacteria, thus leading to abscess formation. ${ }^{1}$ Presentation varies from asymptomatic to death after massive pulmonary embolism and can start during endoscopy or show a delayed onset. Symptoms may resolve over the following days after conservative management. $^{23}$

Contributors We would like to herein confirm that all authors have contributed to the manuscript as appearing in the following statement. VR and KS helped in planning. VR, KS and HR helped 
in conducting the study. VR and KS helped in reporting, conception and design. HR and ST helped in acquisition of data. HR, KS and ST performed the analysis and interpretation of data and helped in reviewing the manuscript. VR, HR, ST and KS approved the final version of the manuscript. Agreement to be accountable for all aspects of the work in ensuring that questions related to the accuracy or integrity of any part of the work were appropriately investigated and resolved by VR, HR, ST and KS.

Funding The authors have not declared a specific grant for this research from any funding agency in the public, commercial or not-for-profit sectors.

Competing interests None declared.
Patient consent for publication Obtained.

Provenance and peer review Not commissioned; externally peer reviewed.

\section{REFERENCES}

1 Jorens PG, Van Marck E, Snoeckx A, et al. Nonthrombotic pulmonary embolism. Eur Respir J 2009;34:452-74.

2 Saraswat VA, Verma A. Gluing gastric varices in 2012: lessons learnt over 25 years. J Clin Exp Hepatol 2012;2:55-69.

3 Al-Hillawi L, Wong T, Tritto G, et al. Pitfalls in Histoacryl glue injection therapy for oesophageal, gastric and ectopic varices: a review. World J Gastrointest Surg 2016:8:729-34

Copyright 2020 BMJ Publishing Group. All rights reserved. For permission to reuse any of this content visit https://www.bmj.com/company/products-services/rights-and-licensing/permissions/

BMJ Case Report Fellows may re-use this article for personal use and teaching without any further permission.

Become a Fellow of BMJ Case Reports today and you can:

- Submit as many cases as you like

- Enjoy fast sympathetic peer review and rapid publication of accepted articles

- Access all the published articles

Re-use any of the published material for personal use and teaching without further permission

\section{Customer Service}

If you have any further queries about your subscription, please contact our customer services team on +44 (0) 2071111105 or via email at support@bmj.com.

Visit casereports.bmj.com for more articles like this and to become a Fellow 